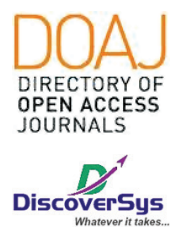

Published by DiscoverSys

\section{Kondisi optimal PCR untuk mendeteksi gen FimH isolat klinis Escherichia coli penyebab infeksi saluran kemih}

CrossMark

\author{
Prisela Zharaswati, ${ }^{1 *}$ Ni Nyoman Sri Budayanti, ${ }^{2}$ Ni Nengah Dwi Fatmawati ${ }^{2}$
}

\section{ABSTRACT}

Background: Urinary tract infection is one of the most common infectious diseases and the second most common infection after respiratory tract infection. Bacteria are the most common cause of urinary tract infections in more than $95 \%$ of cases. Escherichia coli is the most common bacteria that found in $80-90 \%$ of cases of urinary tract infection. The critical virulence factor of Escherichia coli is the type 1 fimbriae with the adhesion subunit, fimH, plays an essential role in the pathogenesis of urinary tract infection.

Aim: The research aims to obtain the optimal condition of PCR in detecting the fimH gene with modification of annealing temperature in the $P C R$ process.
Method: This study used a sample of fimH DNA genes from clinical isolates of $E$. coli causing UTI. The second PCR used an annealing temperature of $57^{\circ} \mathrm{C}$ and a third PCR using an annealing temperature of $64^{\circ} \mathrm{C}$. The electrophoresis results are then viewed with an ultraviolet transilluminator.

Result: The optimization finding showed that the annealing temperature of $52^{\circ} \mathrm{C}, 57^{\circ} \mathrm{C}$, and $64^{\circ} \mathrm{C}$ could detect the fimH gene where the higher the temperature used by $\mathrm{T}_{\mathrm{m}^{\prime}}$ the less the specificity produced. Conclusion: The optimum annealing temperature of PCR to identify the fimH gene from E.coli causes the UTI is in the temperature of $64^{\circ} \mathrm{C}$ with better specificity than of $52^{\circ} \mathrm{C}$. The annealing temperature of $64^{\circ} \mathrm{C}$ indicates the lowest specificity.

Keywords: fimH, PCR, Escherichia coli, urinary tract infections

Cite This Article: Zharaswati, P., Budayanti, N.N.S., Fatmawati, N.N.D. 2019. Kondisi optimal PCR untuk mendeteksi gen FimH isolat klinis Escherichia coli penyebab infeksi saluran kemih. Intisari Sains Medis 10(2): 220-222. D0I: 10.15562/ism.v10i2.236

\title{
ABSTRAK
}

Infeksi saluran kemih merupakan salah satu penyakit infeksi yang sering terjadi dan tergolong infeksi kedua terbanyak setelah infeksi saluran pernapasan. Bakteri merupakan penyebab paling banyak pada kejadian infeksi saluran kemih yaitu lebih dari 95\% kasus. Escherichia coli merupakan bakteri yang paling banyak ditemukan pada kasus infeksi saluran kemih yaitu $80-90 \%$ kasus. Faktor virulensi yang berperan penting dari Escherichia coli adalah fimbrae tipe 1 dengan subunit adhesi, fimH, memiliki peranan penting dalam patogenesis infeksi saluran kemih.

Tujuan: Untuk mendapatkan kondisi optimal PCR dalam mendeteksi gen fimH dengan modifikasi suhu annealing dalam proses $P C R$. Metode: Penelitian ini menggunakan sampel berupa
DNA gen fimH dari isolat klinis E.coli penyebab ISK. PCR kedua menggunakan suhu annealing 57 dan PCR ketiga menggunakan suhu annealing 64. Hasil elektroforesis kemudian dilihat dengan transiluminator ultra violet.

Hasil: Hasil optimasi menunjukkan bahwa suhu annealing $52^{\circ} \mathrm{C}, 57^{\circ} \mathrm{C}$, dan $64^{\circ} \mathrm{C}$ dapat mendeteksi gen fimH dimana semakin tinggi suhu yang digunakan berdasarkan $\mathrm{T}_{\mathrm{m}^{\prime}}$, semakin berkurang spesifitas yang dihasilkan.

Simpulan: Suhu annealing optimal PCR untuk mendeteksi gen fimH dari E.coli penyebab ISK adalah pada suhu $64^{\circ} \mathrm{C}$ dengan spesifitas yang lebih baik daripada suhu annealing $52^{\circ} \mathrm{C}$. Suhu annealing $64^{\circ} \mathrm{C}$ menunjukkan spesifitas yang paling rendah.
'Program Studi Pendidikan Dokter Fakultas Kedokteran Universitas Udayana

${ }^{2}$ Departemen Mikrobiologi Fakultas Kedokteran Universitas Udayana

*Correspondence to: Prisela Zharaswati, Program Studi Pendidikan Dokter Fakultas Kedokteran Universitas Udayana zprisel@gmail.com

Diterima: 08-04-2018

Disetujui: 18-07-2018

Diterbitkan: 01-08-2019
Kata kunci: fimH, PCR, Escherichia coli, infeksi saluran kemih

Cite Pasal Ini: Zharaswati, P., Budayanti, N.N.S., Fatmawati, N.N.D. 2019. Kondisi optimal PCR untuk mendeteksi gen FimH isolat klinis Escherichia coli penyebab infeksi saluran kemih. Intisari Sains Medis 10(2): 220-222. D0I: 10.15562/ism.v10i2.236

\section{PENDAHULUAN}

Infeksi saluran kemih merupakan salah satu penyakit infeksi yang sering terjadi dan tergolong infeksi kedua terbanyak setelah infeksi saluran pernapasan. ${ }^{1}$ Penyakit ini dapat diderita oleh laki laki maupun perempuan dan dapat diderita oleh semua umur. ${ }^{2}$ Berdasarkan data WHO, sebanyak
$50 \%$ perempuan pernah mengalami infeksi saluran kemih selama hidupnya dengan 8,3 juta kunjungan dan 1 juta pasien masuk rumah sakit. ${ }^{3}$

Infeksi saluran kemih dapat disebabkan oleh bakteri, fungi, atau parasit. Namun, bakteri merupakan penyebab paling banyak pada 
kejadian infeksi saluran kemih yaitu lebih dari 95\% kasus. ${ }^{4}$ Bakteri-bakteri yang dapat menyebabkan infeksi saluran kemih adalah Escherichia coli, Enterococcus faecalis, spesies Enterobacter, Staphylococcus saprophyticus, Klebsiella pneumoniae, Proteus mirabilis dan spesies Pseudomonas. ${ }^{1}$ Dari bakteri tersebut, Escherichia coli merupakan bakteri yang paling banyak ditemukan pada kasus infeksi saluran kemih yaitu $80-90 \%$ kasus. $^{2}$ Escherichia coli yang berhubungan dengan infeksi saluran kemih biasa disebut uropathogenic Escherichia coli (UPEC). UPEC merupakan bakteri batang gram negatif yang berasal dari saluran gastrointestinal yang dapat menuju ke vagina dan periuretra yang dapat bergerak naik ke uretra, kandung kemih, bahkan dapat berkolonisasi di ginjal..$^{5}$

Kemampuan E.coli untuk menyebabkan infeksi saluran kemih berhubungan erat dengan adanya faktor virulensi yang berkaitan dengan kolonisasi, persistensi, dan patogenesis dari ISK. ${ }^{6}$ Bagian terpenting dari faktor virulensi ini termasuk adhesin atau fimbrae, pembentukan biofilm, dan toksin. ${ }^{7}$ Faktor virulensi yang berperan penting dari E.coli penyebab ISK adalah fimbrae tipe 1 yang merupakan faktor virulensi terbanyak pada kejadian infeksi saluran kemih. ${ }^{7,9}$

Kemampuan E.coli untuk menyebabkan infeksi saluran kemih yang berhubungan dengan faktor virulensi khususnya fimbrae tipe 1 dengan subunit adhesi, fimH, merupakan bagian yang paling penting dalam patogenesis infeksi saluran kemih. Hal ini berhubungan dengan gejala klinis dan rencana terapi bagi penderita infeksi saluran kemih sehingga dapat menurunkan morbiditas maupun mortalitas dari infeksi saluran kemih yang diakibatkan oleh bakteri Eschericia coli.

Untuk mendeteksi gen fimH pada Escherichia coli penyebab infeksi saluran kemih, dapat dilakukan dengan menggunakan teknik molekuler yaitu PCR. Kondisi optimal PCR sangat mempengaruhi tingkat keakuratan hasil PCR termasuk dalam mendeteksi gen fimH. Optimasi PCR dilakukan untuk mendapatkan kondisi optimal dalam mendeteksi gen fimH dari E.coli penyebab ISK.

\section{METODE}

Penelitian ini menggunakan sampel berupa DNA gen fimH dari isolat klinis E.coli penyebab ISK. DNA template untuk amplifikasi PCR didapatkan dengan metode boiling yang kemudian diambil supernatannya. Sekuens dari primer yaitu primer fimH (F): 5'-GTG CCA ATT CCT CTT ACC GTT-3'dan primer fimH (R): 5'-TGG AAT AAT
CGT ACC GTT GCG-3..10 Volume total PCR mix adalah 10 yang mengandung 5 Promega Master Mix, 0,3 primer fimH(F) (0,3 M) 0,3 primer fimH $(\mathrm{R})(0,3 \mathrm{M}), 3,6 \mathrm{H}_{2} \mathrm{O}$, dan 0,8 DNA template. Proses elektroforesis memakai gel agarosa $2 \%$, TBE 1x dan DNA ladder 100 bp.

Proses PCR terdiri dari tahap pra denaturasi suhu dalam 2 menit, denaturasi suhu dalam 1 menit, annealing dalam 45 detik dengan suhu 52, dan extension suhu selama 1 menit, final extension suhu selama 5 menit. Siklus diulang sebanyak 35 kali. PCR kedua menggunakan suhu annealing 57 dan PCR ketiga menggunakan suhu annealing 64.

Elektroforesis dilakukan dengan bubuk agarose $2 \%$ dalam TBE 1x yang ditambahkan dengan Gelred 1. Elektroforesis kemudian dijalankan dengan TBE $0,5 \mathrm{x}$ dengan tegangan 100 volt selama 35 menit. Hasil elektroforesis kemudian dilihat dengan transiluminator ultra violet.

\section{HASIL}

Gambar 1 menunjukkan hasil PCR dengan perbedaan suhu annealing. Kolom 1 (sampel) dan kolom 2 (kontrol negatif) pada suhu annealing $52^{\circ} \mathrm{C}$, kolom 3 (kontrol negatif) dan kolom 4 (sampel) pada suhu annealing $57^{\circ} \mathrm{C}$, kolom 5 (kontrol negatif) dan kolom 6 (sampel) pada suhu annealing $64^{\circ} \mathrm{C}$, dan $\mathrm{M}$ sebagai Marker DNA ladder 100bp. Hasil menunjukkan bahwa ketiga suhu annealing yang digunakan dapat mendeteksi gen fimH seperti ditunjukkan pada gambar 1 kolom 1, 4, dan 6 dengan ukuran 164 bp yakni berada di antara 200 dan 100. Kolom 2, 3, dan 5 (kontrol negatif) tidak terlihat pita pada hasil PCR.

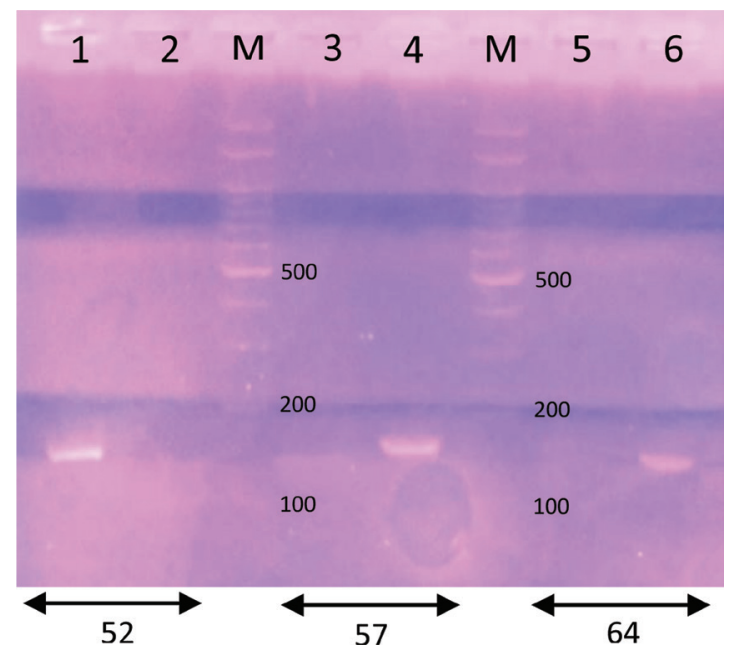

Gambar 1 Hasil PCR berdasarkan optimalisasi suhu annealing 


\section{DISKUSI}

Hasil menunjukkan bahwa pada tiga suhu annealing yang digunakan, dihasilkan pita fragmen DNA. Namun, hasil pita yang terbentuk menunjukkan adanya perbedaan spesifitas yang ditunjukkan pada perbedaan ketebalan pita. Hal ini disebabkan karena adanya perbedaan perlakuan pada sampel yakni perbedaan suhu annealing yang digunakan sehingga mempengaruhi hasil dari amplifikasi. Tm primer menjadi dasar dalam pemilihan suhu annealing. Berdasarkan perhitungan Tm dengan rumus; $\mathrm{Tm}=2(\mathrm{~A}+\mathrm{T})+4(\mathrm{G}+\mathrm{C})$ didapatkan $\mathrm{Tm}$ primer $\mathrm{F}$ sebesar $62^{\circ} \mathrm{C}$ dan $\mathrm{Tm}$ primer $\mathrm{R}$ sebesar $62^{\circ} \mathrm{C}$. Suhu annealing yang digunakan umumnya $10^{\circ} \mathrm{C}-5^{\circ} \mathrm{C}$ dibawah $\mathrm{Tm}$ primer sehingga suhu yang digunakan yaitu $52^{\circ} \mathrm{C}-57^{\circ} \mathrm{C}$. Adapun penggunaan suhu annealing $64^{\circ} \mathrm{C}$ sesuai dengan penelitian yang dilakukan oleh Hohjati (2015).10 Pada kondisi suhu annealing $52^{\circ} \mathrm{C}, 57^{\circ} \mathrm{C}$, dan $64^{\circ} \mathrm{C}$ terbentuk pita berukuran $164 \mathrm{bp}$ yakni berada di antara $200 \mathrm{bp}$ dan 100 bp. Namun, terdapat perbedaan spesifitas di antara produk PCR tersebut dimana pada produk PCR dengan suhu annealing $52^{\circ} \mathrm{C}$ memiliki spesifitas yang lebih tinggi diantara produk PCR dengan suhu annealing yang lain, diikuti dengan produk PCR pada suhu annealing $57^{\circ} \mathrm{C}$, lalu pada produk PCR dengan suhu $64^{\circ} \mathrm{C}$ memiliki spesifitas yang lebih rendah dibanding produk PCR dengan suhu annealing yang sebelumnya. Hal ini dapat dilihat dari ketebalan pita dimana ketebalan pita yang dihasilkan semakin berkurang ketebalannya seiring dengan peningkatan suhu annealing yang digunakan. Penggunaan suhu annealing yang lebih tinggi menyebabkan terjadinya penurunan spesifitas akibat terhambatnya hibridisasi template sehingga primer tidak dapat menempel dengan baik pada DNA target yang menghasilkan spesifitas produk PCR yang lebih rendah seperti yang ditunjukkan pada gambar 1.

Pada kolom 2, 3, dan 5 dengan suhu annealing $52^{\circ} \mathrm{C}, 57^{\circ} \mathrm{C}$, dan $64^{\circ} \mathrm{C}$ merupakan kontrol negatif sehingga tidak terbentuk pita. Hasil penelitian ini menunjukkan bahwa semakin tinggi suhu annealing yang digunakan berdasarkan rumus $\mathrm{Tm}$, maka semakin berkurang spesifitas produk PCR yang dihasilkan.

\section{SIMPULAN}

Suhu annealing optimal PCR untuk mendeteksi gen fimH dari E.coli penyebab ISK didapatkan pada suhu annealing $52^{\circ} \mathrm{C}, 57^{\circ} \mathrm{C}$, dan $64^{\circ} \mathrm{C}$ dengan spesifitas yang lebih baik pada suhu annealing $52^{\circ} \mathrm{C}$. Suhu annealing $64^{\circ} \mathrm{C}$ menunjukkan spesifitas yang paling rendah.

\section{DAFTAR PUSTAKA}

1. Hotchandani R and Aggarwal KK. Urinary Tract Infections in Women. Ind J Clin Practice. 2012;187-192.

2. Iranpour D, Hassanpour M, Ansari H, Tajbakhsh S, Khamisipour G, Najafi A. Phylogenetic groups of Escherichia coli strains from patients with urinary tract infection in Iran based on the new Clermont phylotyping method. Biomed Res Int. Hindawi Publishing Corporation. 2015: 5-11.

3. World Health Organization. Cauda UTI - ECCMID Dec 2011DEF.ppt. http://www.who.int/gpsc/information_ centre/cauda-uti_eccmid.pdf?ua=1 (Akses: 30 April 2018).

4. Daoud Z, Afif C. Escherichia coli Isolated from Urinary Tract Infections of Lebanese Patients between 2000 and 2009: Epidemiology and Profiles of Resistance. Chemother Res Pract. 2011; 1-6.

5. Rogers EMC, Peterson ND, Hilbert DW. Uropathogenic Escherichia coli: the pre-eminent urinary tract infection pathogen; 2011: 1-66 p.

6. Minardi D, d'Anzeo G, Cantoro D, Conti A, Muzzonigro G. Urinary tract infections in women: etiology and treatment options. Int J Gen Med. 2011;4:333-43.

7. Tabasi M, Reza M, Karam A, Habibi M. Phenotypic Assays to Determine Virulence Factors of Uropathogenic Escherichia coli ( UPEC ) Isolates and their Correlation with Antibiotic Resistance Pattern. Osong Public Heal Res Perspect. Elsevier Korea LLC; 2015;6(4):261-8.

8. Tiba MR, Yano T, Leite DDS. Genotypic characterization of virulence factors in Escherichia coli strains from patients with cystitis. Rev Inst Med Trop Sao Paulo. 2008;50(5):255-60.

9. Slavchev G, Pisareva E, Markova N. Virulence of Uropathogenic Escherichia Coli. J Cult Collect. 2008;6:3-9.

10. Hojati Z, Molaie R, Gholipour A. The FimH Gene in Uropathogenic Escherichiacoli Strains Isolated From Patient With Urinary Tract Infection. Jundishapur J Microbiol [Internet]. 2015;8(2):12-5.

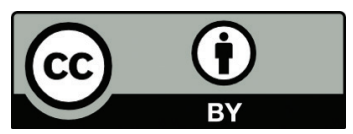

This work is licensed under a Creative Commons Attribution 